\title{
Management Strategy On Lake Toba Development Being 10 Main Tourism Destinations In Indonesia
}

\section{Nicholas Marpaung1, Monica Beatrice Hutabarat², Wiro Oktavius Ginting3}

\author{
Department of Business Administration ${ }^{12}$, Department of Public Administration ${ }^{3}$ \\ Diponegoro University. Semarang, Indonesia \\ nicholasmarpaung@rocketmail.com¹, mocabeatrice@gmail.com²,wirooktaviusginting@ymail.com ${ }^{3}$
}

\begin{abstract}
Lake Toba is the largest freshwater lake in Indonesia and in Southeast Asia, but its tourism potential has not been managed properly.Currently, the government is committed to build and develop the area of Lake Toba by inclusion in to 10 main tourism destinations that will be developed by Indonesian government.This study examines how management strategies in the development of Lake Toba to be one of the main tourism destinations in Indonesia.This study used descriptive qualitative approaches and also incorporates a literature review on tourism development and case study.The government focused the development on Accessibility, Amenities and Attraction. The right implementation strategieslike air acces development and optimizing festival improved tourist visits to Lake Toba in recent years.
\end{abstract}

Keyword: Management strategy, Tourism, Lake Toba, Accessibility, Amenities, Attraction

\section{INTRODUCTION}

Tourism is one of the fastest-growing industries in the second half of the twentieth century, and is often used as a key for economic growth in both developed and developing countries(Font \& Ahjem, 2007). The tourism sector is considered to provide large amount of income for country that enhances and manages the potentential of tourism properly. Indonesian government realizes the importance of the tourism sector managed appropriately to increase national revenue. Beside bali and raja ampat, indonesia government is in effort to develop 10 main tourist destinations in indonesia namely Tanjung Layang Belitung, Tanjung Lesung Banten, Seribu Island, Borobudur Temple, Mount Bromo, Malerita, Komodo Island, Wakatobi, Morotai and including lake toba in north sumatera province.Lake toba in north sumatera was created by toba supervolcano explosion for more than74.000 years ago. With natural beauty that lake toba has, this region has no necessary difficulties to attract tourist to visit. However, the lack of information and infrastructure and ineffective management strategy are reasons why tourist visit never beyond than 180.000 every year. The purpose of development plan initiated by the government is toreach 1 million tourist by 2020. The government has established Board of Authority Lake Toba Tourism (BOALT) to accelerate the development and restoration of the lake environment.

Reference (Fazenda, da Silva, \& Costa, 2010)management strategy on developing tourism is growing importance as it offers a process for coordinating the management of all elements that make the destination up (attractions, amenities, access, marketing and pricing).The management strategy is designed to formulate and implement the strategies to develop the potential of Lake Toba and reach the target of visit and economic improvement of lake Toba environment.Development plan has implemented such as by opening accesibility to Lake Toba, culture performances on promotion order, and development the supporting infrastructure in lake toba area. 


\section{LITERATURE REVIEW}

\section{A. Management strategy}

Management strategy is process and series of activities to take thorough and fundamental decisions and accompanied by stipulation about guidance of implementation. Basically the processof strategymanagement is divided into four main parts: strategy formulation, strategy implementation, and evaluation and control (Wheelen, 2008).

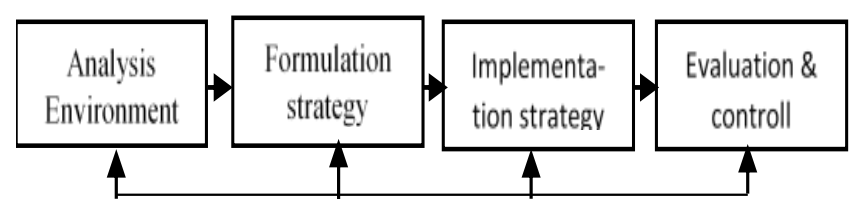

Fig. 1. Process of Management Strategy(Wheelen, 2008)

According to (Analoui \& Akram, 2013) management strategy begins with environment analysis continued developing strategy, implementation and finalized with evaluation. The sequences of process of management strategy define that management strategies as a structure that promotes the understanding and integration of all the main phases of the formulation and implementation of the strategy (Pearce \& Robinson, 2007). Purpose of strategic management is the creation of future-oriented system that contain environment configuration and internal(Pechlaner \& Sauerwein, 2008).

\section{B.Tourism development}

Tourism has traditionally been considered an effective instrument for social and economic development. Countries all over the world have included tourism among their instruments and sectoral policies toward development, and many cooperation agencies have funded and carried out project in this area (Fayos, Moraleda, \& Isabel, 2015). Tourism is seen by many regions and countries as a quick and easy solution to overcome the lack of economy sector (Font \& Ahjem, 2007). Development of tourism requires careful coordination and cooperation of all parties to take decisions on the development of a sustainable tourism industry. Tourism development must be supported by cooperation between stakeholders, synergy, balance, social and cultural responsibility (Cortez, 2010). The opinion is also supported by (Heath, 2014) that the successful implementation of the strategy will require multilevel partnerships, collaboration, and coordination between the public and private sectors, civil society and citizens development of the tourism sector is not only by promoting the natural beauty, but also by fulfilling what is required tourists is related to accessibility, the environment and technology.

\section{RESEARCH METHOD}

The research uses qualitative research approaches with descriptive. The methodology also incorporates a literature review on tourism development and a case study. Collecting primary data (interview, observation and documentation) and secondary data (collection of archive and document archive-related institution). The informant are government represented by stakeholders in the tourism ministry and department of culture and tourism North Sumatera province. The focus of research is related to the strategic managementstarts from planning to evaluation on the strategy development of lake toba, wherepresented the models and tools are applied to the lake toba development.

\section{RESULT AND DISCUSSION}

\section{A. Phase 1-analysis environment LakeToba-an overview}

Lake Toba has an important role in the system of socio-cultural and economic of Lake Toba region. In the context of the socio-cultural, lake toba is the pride and identity of local communities especially Bataknese in indonesia and even in the world. This lake is a testament to the history of Batak tribe civilization as one of the largest ethnic group in Indonesia. Local communities uphold the customs value and sanctity of this lake. While the economic context, this lake is the source of livelihood of people by utilizing the waters of lake toba as cageculture sector and the tourism industry.

Currently lake loba has already been registered as a UNESCO Global Geopark Network 
and the assessors of UNESCO has been doing research before assign lake toba as a world heritage geopark. Lake toba region is surrounded by mountainous land (mountain chain) that make the lake is very beautiful and has a potential as tourist destination. Lake toba is also the border point 7 districts in north sumatra and has similar interests in the use, development and conservation of lake toba.

However, with all potentials, Lake Toba area is still not capable of being the main destination of local and foreign tourists destination Indonesia. Access to lake toba takes quite longto reach. Tourist does not have many choice with regard to infrastructure facilities. Environmental problems also affect the development of the region especially the cleanliness and preservation of lake toba, which began to be contaminated by fish feed, manure and other type of wastes. But in this context, the Indonesian government has been committed to develop lake toba becomes a main destination in Indonesia with the restoration and accelerate the construction dan lake toba development.

\section{Tourism Supply}

The main tourism resources of Lake Toba area are the following: Samosir Island, batak culture (Heritage), batu gantung (hanging stone), Monkey Park, aek natonang (quitness water is lake above lake and located in samosir island), sipiso-piso waterfall and landscape. Taking into consideration the tourism resources of the region, the main products of Lake Toba:

1. Historic and cultural tourism (touring);

2. Nature tourism-geopark tourism

\section{Tourism Demand}

The entry point for the lake toba region is the city of Medan, the third largest city in Indonesia.Kuala Namu International Airport in Medan is considered the most important airport in the North Sumatera, especially in terms of traffic volume and destination connectivity. The area of lake toba and towns around lake toba has supported by five star hospitality and the hotel with low cost. The Indonesian government has obtained investment commitments from employers to build upscale hospitality area.

\section{SWOT analysis}

After a brief presentation of Lake Toba, it is important to highlight the main strengths, weaknesses, opportunities and threats of the region. This step is aim to analyze of strategy by focusing attention on the strengths, weaknesses, opportunities and threats that critical to the success of the strategy. With analyze the potential of the environment, it will be easier to formulate sustainable strategies and accelerate in obtaining additional information. The following is a analysis SWOT of the area of Lake Toba (Table. 1)

Table. I Analysis SWOT of Lake Toba region

\begin{tabular}{|c|c|}
\hline Strengths & Weakness \\
\hline $\begin{array}{l}\text { 1. Largest tecto-volcanic } \\
\text { lake in south east asia } \\
\text { 2. Samosir island (Island in } \\
\text { the middle of the lake) } \\
\text { 3. A huge historical and } \\
\text { archaeological patrimony } \\
\text { 4.A diversified tourism } \\
\text { supply (eco-rural tourism, } \\
\text { nature and local culture and } \\
\text { ethnic) } \\
\text { 5. History tourism- lake } \\
\text { toba, and batak ethnic }\end{array}$ & $\begin{array}{l}\text { 1. Accessibilities in and to the } \\
\text { region requiring } \\
\text { 2. Low Educational level of the } \\
\text { community } \\
\text { 3.Insufficient accommodation } \\
\text { capacity, amenities, and } \\
\text { attraction } \\
4 \text {. A lack of awareness of } \\
\text { protecting the Lake Toba } \\
\text { environment } \\
5 \text { Ineffective coordination } \\
\text { among local authorities }\end{array}$ \\
\hline $\begin{array}{l}\text { 1. Political commitment and } \\
\text { institutional mobilization to } \\
\text { develop the region } \\
\text { 2. Private tourism } \\
\text { investments in course } \\
\text { 3. Modenized sibisa airport } \\
\text { and silangit airport } \\
\text { 4. Opening new route flights } \\
\text { to Lake Toba region } \\
5 \text {. Lake toba as world } \\
\text { heritage by UNESCO }\end{array}$ & $\begin{array}{l}\text { 1. Continuous process of } \\
\text { diversification } \\
\text { 2. Persistence of the main } \\
\text { infra-structural problems of } \\
\text { the region (accessibilities, etc.) } \\
\text { 3. Loss of opportunities in the } \\
\text { attraction of new tourism } \\
\text { investments to other regions } \\
\text { (as a result of a slow and } \\
\text { complex process in the } \\
\text { approval of projects) }\end{array}$ \\
\hline
\end{tabular}

\section{B. Goals and Strategies of Lake Toba Development}

To accelerate the development of Lake Toba, the Indonesian government has formulated the ultimate goal, a strategic plan and sustainable evaluation stage. Ultimate Goals formulated under existing conditions, ultimate analysis and profiles 
Lake Toba to be achieved. Goals of Lake Toba development consider some points as shown in the figure below.

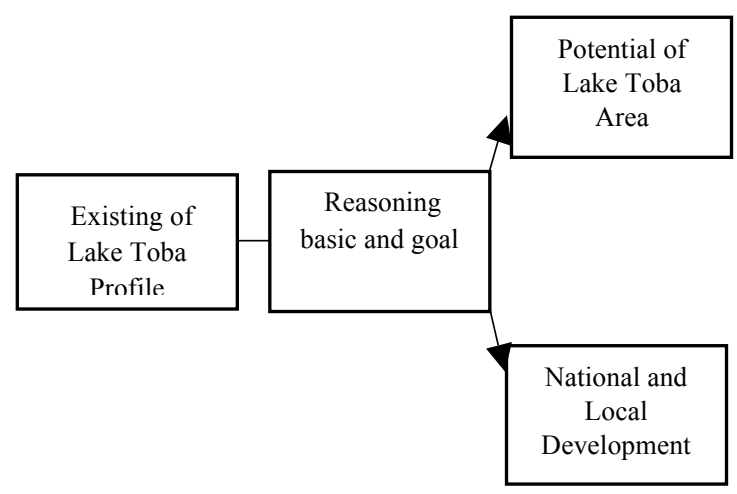

Fig. 2. Process of Management Strategy(Wheelen, 2008)

The formula ofgovernment to developis "Realizing the Lake Toba region as a Water source of Life Community, Center of Batak community village and World class tourism region". To achieve these targets, the government assigns three guidelines development focuses- accessibility, amenities and attractions. The government also sets up a development scenario of lake toba, which will be a reference for the formulation of development direction, strategy, and become a benchmark for evaluating the extent to which the stage has been reached. Term of target will be achieved in 20 years, through four stages with each stage during the five years that (Reinforcement, Development, Integration, Expansion).

\section{Implementation strategies for Lake Toba development}

The government's first strategic step in the effort to implement the tourism development of Lake Toba is by establishing a Board of Authority Lake Toba Tourism (BOALT). BOALT was established by regulation of president number 49 in 2016 and responsible for policy, management, construction and development of Lake Toba. BOALT comes with some elements of ministries, local governments of North Sumatra province, government officials and professionals who will cooperate and work together in the development of Lake Toba. BOPDT performance so far has managed to attract private investment, especially in the hospitality sector and transport investment Lake Toba.

Beside to form BOALT, the following is the implementation strategy of the development of Lake Toba with a focus on the development of accessibility, amenities and attractions are already running.

Table II. Lake Toba Focus Development and Implementation

\begin{tabular}{|c|c|c|}
\hline Num & Focus Development & Implementation \\
\hline 1 & Accessibility & $\begin{array}{l}\text { 1. The development of air } \\
\text { access; the construction } \\
\text { of the airport runway- } \\
\text { Silangit airport and sibisa } \\
\text { airport } \\
\text { 2. Construction of Higway } \\
\text { to connect Medan-Tebing } \\
\text { Tinggi-Siantar-Parapat } \\
\text { cities }\end{array}$ \\
\hline 2 & Amenities & $\begin{array}{l}\text { 1 Normalization of Lake } \\
\text { Toba } \\
\text { 2. Deepening and } \\
\text { dredging the tano } \\
\text { ponggol waters area } \\
\text { 3. The provision of } 500 \\
\text { hectares of land eco- } \\
\text { tourism } \\
\text { 4. Development of } \\
\text { Tourist Resort }\end{array}$ \\
\hline 3 & Attraction & $\begin{array}{l}\text { 1. Develop Cultural } \\
\text { Festival-Festival of Lake } \\
\text { Toba } \\
\text { 2. Promotion of culture } \\
\text { and history of Lake Toba }\end{array}$ \\
\hline
\end{tabular}

Besides the focus on infrastructure development, additional steps to undertake the development of Lake Toba tourism marketing (branding, advertising, and sales), human resource development, and the tourism industry (local and national).

\section{Evaluation}

The evaluation phase is the final step in the process of strategic management. Formulation and strategy implementation of Lake Toba of becoming 10 main tourist destinations in Indonesia will be evaluated to determine the effectiveness and achievement. Evaluation will be conducted by assessing the BOALT performance, 
implementation strategies based on the focus of development (Asccessibiliy, Amenities and Attractions) and the extent to which stage of development of Lake Toba has been achieved. There are 4 stages which have been prepared government that will become a benchmark for the evaluation are as follows

Reinforcement Stage: The strengthening in the next 5 years from 2016 to 2018, which is the restoration of Lake Toba, infrastructure development and diversification of the local superior products.

Development Stage : Lake Toba will enhance cleanliness and growing of local products between 2019-2021.

Integration Stage: Lake Toba will evolve into a national tourist destination that is integrated with the local production centers between 2022-2024.

Expansion Stage: Lake Toba expected to be global destination with a global levelAsia-Pacific marketing between 2023-2027.

\section{CONCLUSION}

Strategic management can be enforced on the whole organization (private, state or independent) on a wide range activity. This study shows that the management strategies in developing Lake Toba has been running on the right track with primary focus is the development of accessibility, amenities and attractions. Development of accessibility such as highway and operations Sibisa and Silangit airport has been a lot easier for tourists to reach the Lake. Cultural events such as Lake Toba festivals provide effective results in attracting tourists visit in 2016.The establishment of BOALT is a strategic step to begin construction and development of Lake Toba because the objectives will be achieved based on the BOALT performance. Lake Toba development process is still at the stage of reinforcement, it means that there are still some steps that must be encouraged to make Lake Toba becomes 10 main tourist destinations in Indonesia, and other strategies urge to be conducted soon.

\section{ACKNOWLEDGEMENT}

My profound gratitude to the North Sumatra province government, head of department of culture and tourism for their support for this work.

\section{REFERENCES}

Analoui, F., \& Akram, S. (2013). Strategic management : the case of NGOs in Palestine. Management Research Review, 35(6), 473489.

https://doi.org/10.1108/01409171211238 253

Cortez, S. L. (2010). Strategies for the development of sustainable tourism in the Amazon rainforest of Bolivia. Worldwide Hospitality and Tourism, 2(2), 136-143. https://doi.org/10.1108/17554211011037 822

Fayos, E., Moraleda, L., \& Isabel, A. (2015). Knowledge Management in Tourism: Policy and Governance Applications Tourism for Development Article information:Bridging Tourism Theory and Practice (Vol. 4). Emerald Group Publishing Ltd. https://doi.org/10.1108/S20421443(2012)0000004004

Fazenda, N., da Silva, F., \& Costa, C. (2010). Douro Valley Tourism Plan. Worldwide Hospitality and Tourism Themes, 2(4), 428-440. https://doi.org/10.1108/17554211011074 074

Font, X., \& Ahjem, T. E. (2007). Searching for a balance in tourism development strategies. Contemporary Hospitality Management, 11(2/3), 73-77. https://doi.org/10.1108/09596119610152 041

Heath, E. (2014). Tourism as an Instrument for Development: A Theoretical and Practical Study Article information:Bridging Tourism Theory and Practice (Vol. 5). Emerald Group Publishing Limited. https://doi.org/10.1108/S2042144320140000006021

Pearce \& Robinson, R. (2007). Strategic 
Management: Formulation, Implementation and Control. New York: McGraw-Hill.

Pechlaner, H., \& Sauerwein, E. (2008). Strategy implementation in the Alpine tourism industry. Contemporary Hospitality Management, 14(4), 157-168. https://doi.org/10.1108/09596110210427 003

Wheelen. (2008). Strategic Management and Business Policy. London: Prentice Hall. 